\author{
Anna Kurowska \\ Instytut Polityki Społecznej, Uniwersytet Warszawski \\ a.kurowska@uw.edu.pl
}

Ewelina Stotwińska-Rosłanowska

Szkoła Główna Handlowa w Warszawie

roslanowska@gmail.com

\title{
ZATRUDNIENIE A PIERWSZE I DRUGIE URODZENIA WŚRÓD KOBIET W POLSCE ${ }^{1,2}$
}

\begin{abstract}
WSTĘP
Niska dzietność, uniemożliwiająca proste zastępowanie pokoleń, jest obecnie problemem wielu wysoko rozwiniętych krajów. Wraz z wydłużaniem się życia ludzkiego jest ona w wielu krajach Europy przyczyną szybkiego starzenia się ludności oraz spadku jej dynamiki. Wielkość i struktura wieku populacji mają kluczowe znaczenie dla potencjału rozwojowego europejskich gospodarek, stanu finansów publicznych i poziomu życia ludności w kolejnych dziesięcioleciach. W Polsce w 2012 roku odnotowaliśmy najniższy poziom dzietności wśród wszystkich krajów Unii Europejskiej (UE). Współczynnik dzietności ogólnej (TFR - total fertility rate) dla Polski wynosił 1,3, a średnia dla krajów unijnych (UE 27) wynosiła 1,57. Natomiast jeszcze w 1990 roku nasz kraj znajdował się w czołówce państw europejskich z najwyższą dzietnością (por. wykres 1). Dlatego też jednym z głównych tematów dzisiejszych debat publicznych i politycznych jest kwestia znalezienia odpowiednich rozwiązań w zakresie polityki rodzinnej, zatrudnienia czy - szerzej - polityki społecznej, które pozytywnie wpłynęłyby na dzietność w naszym kraju. W tym

1 Artykuł przygotowany w ramach projektu pt. Joint influence of family and labour market participation and fertility decisions of men and women, finansowanego ze środków własnych Fundacji na rzecz Nauki Polskiej w ramach programu Pomost Powroty, którego kierownikiem jest dr Anna Kurowska. E-mail: a.kurowska@uw.edu.pl.

2 Autorki bardzo dziękują Pani Profesor Irenie E. Kotowskiej oraz Recenzentom za cenne uwagi do prezentowanego $\mathrm{w}$ artykule modelu.
\end{abstract}


kontekście istotnym zagadnieniem jest pytanie o determinanty decyzji, o posiadaniu (kolejnego) dziecka wśród polskich kobiet.

W związku z ostatnią reformą wydłużenia urlopów macierzyńskich/rodzicielskich do jednego roku i jednocześnie niskim poziomem zatrudnienia matek małych dzieci w Polsce (por. Kocot-Górecka i Kurowska 2013, Kurowska 2013), celem naszych analiz było podjęcie próby zbadania wpływu statusu aktywności zawodowej kobiety oraz długości prawnie przysługującego urlopu macierzyńskiego w okresie bezpośrednio poprzedzającym poczęcie dziecka, a także historii zawodowej kobiety na prawdopodobieństwo urodzenia pierwszego i drugiego dziecka przez kobiety urodzone w 1960 roku lub później.

Jak wynika z syntezy badań empirycznych (metaanaliza dokonana przez Matysiak i Vignoli (2008)), w krajach Europy Zachodniej praca kobiet ogranicza dzietność, choć negatywny wpływ zatrudnienia jest słabszy w krajach o niższym poziomie niekompatybilności życia rodzinnego z zatrudnieniem (np. w krajach nordyckich). Jedynie dwa badania, przywoływane przez Matysiak i Vignoli (2008) dla krajów Europy Środkowej pokazują, że pomimo wysokiej niekompatybilności macierzyństwa i pracy zawodowej kobiet zależność między zatrudnieniem kobiet a dzietnością jest nieistotna. Autorzy thumaczą to występowaniem tzw. selekcji pozytywnej polegającej na tym, że kobiety podejmują pracę przed urodzeniem (kolejnego) dziecka oraz silnym oddziaływaniem efektu dochodowego: wyższe łączne dochody rodziny umożliwiają realizację zamierzeń prokreacyjnych, które w sytuacji niewystarczających dochodów mężczyzny (jako jedynego żywiciela w rodzinie) nie mogłyby zostać zrealizowane. Potwierdzają to wyniki analiz dla Polski przeprowadzone przez Matysiak (2009, 2011), w których zastosowała wieloprocesowy model hazardu pozwalający na uwzględnienie nieobserwowanej heterogeniczności i eliminację powodowanych przez nią efektów selekcji. Pokazują one, że zatrudnienie kobiet wywiera negatywny wpływ na ryzyko posiadania dziecka. Zgodnie z wyjaśnieniami autorki oznacza to, że kobiety w Polsce charakteryzują się nieobserwowalną skłonnością do podejmowania pracy zawodowej przed urodzeniem dziecka i mimo silnej niekompatybilności między aktywnością zawodową i rodzinną traktują pracę zawodową jako warunek do posiadania dzieci.

Jak wynika z badań Rønsen (1999, 2004), wydłużenie urlopu macierzyńskiego miało pozytywny wpływ na dzietność w Finlandii i Norwegii. Na pozytywny wpływ wydłużenia urlopu wychowawczego na dzietność wskazują również badania Lalive i Zweimuller (2005) przeprowadzone dla Austrii. W naszych analizach chcemy sprawdzić, czy dłuższy urlop macierzyński, a zatem dłuższy okres płatnego urlopu przypadającego bezpośrednio po urodzeniu dziecka, sprzyjał dzietności polskich kobiet.

Sposób, w jaki praca zawodowa wpływa na zachowania prokreacyjne kobiet, uzależniony jest od uwarunkowań strukturalnych i kulturowych determinujących poziom/zakres niekompatybilności ról zawodowych i rodzinnych (Liefbroer i Corijn 1999). Uwarunkowania kulturowe odnoszą się do społecznych norm i wartości, 
które definiują role kobiety w społeczeństwie, w szczególności w odniesieniu do takich aktywności, jak opieka nad dzieckiem oraz praca zawodowa. Uwarunkowania strukturalne obejmują natomiast faktyczne możliwości i ograniczenia w pełnieniu określonych ról przez kobiety i mężczyzn, do których można zaliczyć m.in. dostęp do zatrudnienia, urlopów macierzyńskich czy zewnętrznej opieki nad dzieckiem. W Polsce zagadnienie konfliktu strukturalnego i kulturowego było po raz pierwszy omawiane przez Kotowską $(2002,2004)$ oraz Muszyńską (2003), później zaś również m.in. przez Matysiak (2011). Nasze analizy, uwzględniające długość urlopów macierzyńskich - będących elementem uwarunkowań strukturalnych, wpisują się więc w nurt badań nad konfliktem ról zawodowych i rodzinnych polskich kobiet.

Wykres 1. Współczynnik dzietności w 24 krajach Unii Europejskiej w 1990 i 2011 roku Figure 1. Total fertility rate in the 24 European Union countries in 1990 and 2011

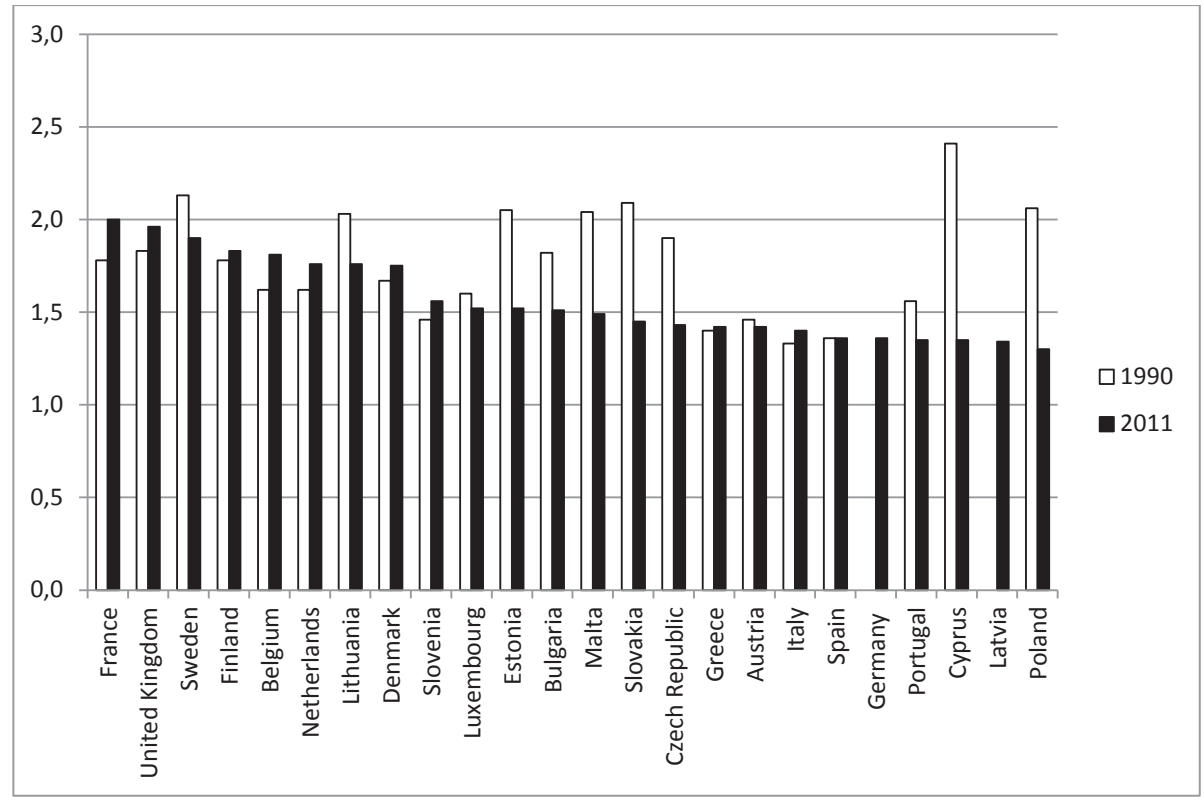

Źródło: Opracowanie własne na podstawie danych z bazy Eurostat.

Source: Own elaboration based on data from the Eurostat database. 


\section{UZASADNIENIE WYBORU METODY ANALITYCZNEJ ${ }^{3}$}

W światowej literaturze przedmiotu istnieje wiele badań na temat czynników mających wpływ na dzietność kobiet. Są to zarówno badania wykorzystujące dane zagregowane, jak i dane indywidualne. $\mathrm{W}$ przypadku analiz na danych zagregowanych jednostkami badania są zazwyczaj kraje lub inne jednostki geograficzno-polityczne, zaś zmienną objaśnianą współczynnik dzietności (por. np. Zhang i in. 1994, Ekert 1986, Cigno i Ermisch 1989, Büttner i Lutz 1990, Hyatt i Milne 1991, Hoem 1993, Walker 1995, Gauthier i Hatzius 1997, Castles 2003, Bjorklund 2006). Dane indywidualne, wykorzystywane w analizach determinant dzietności, to przede wszystkim dane pochodzące ze spisów powszechnych lub rejestrów ludności (por. np. Olausson i in. 2001, Vikat 2004, Andersson i in. 2004, Milligan 2005, Andersson $\mathrm{i}$ in. 2006, Neyer i Andersson 2008, Rindfuss i in. 2010), a także z badań ankietowych realizowanych na reprezentatywnych próbach, takich jak np. badania aktywności ekonomicznej/zatrudnienia ludności/kobiet w wieku produkcyjnym (np. Ermisch 1991, Laroque i Salanié 2004, 2005), badania budżetów gospodarstw domowych (np. Del Boca 2002), oraz szersze tematycznie badania dotyczące życia rodzin/ludności (np. Hoem i in. 2001, Olah 2003, Hank i Kreyenfeld 2003, Rønsen 2004). Spośród analiz realizowanych na danych indywidualnych, na szczególną uwagę zasługują te, które realizowane są z wykorzystaniem badań panelowych lub badań retrospektywnych zawierających informacje dotyczące historii zatrudnienia, dzietności oraz innych zdarzeń w przebiegu życia kobiety, istotnych z punktu widzenia zachowań prokreacyjnych. Takie dane umożliwiają uwzględnienie kolejności wystąpienia tych zdarzeń, co w większym stopniu uwiarygadnia wnioskowanie na temat związków przyczynowo-skutkowych niż analizy przekrojowe. Narzędziem analiz są na ogół jednoprocesowe modele hazardu (por. np. Ermisch 1991, Rønsen 1999, 2004, Hoem 2000, Hoem i in. 2001, Olah 2003, Vikat 2004, Adsera 2005, Andersson i in. 2006). Rzadziej sięga się po wieloprocesowe modele hazardu (np. Matysiak 2009, Di Tommaso 1999) czy modele wielopoziomowe (np. Hank i Kreyenfeld 2003).

By ocenić wpływ wyselekcjonowanych zmiennych na wystąpienie zdarzeń urodzenia pierwszego i drugiego dziecka zastosowano model proporcjonalnego hazardu Coxa postaci:

$$
\log h_{i}(t)=\alpha(t)+\beta_{i} x_{i l}+\beta_{k} x_{i k}(t)
$$

\footnotetext{
3 W artykule wykorzystano, m.in., przeglądy literatury w zakresie determinant dzietności rozważanych w analizach ilościowych, przygotowane na wewnętrzne potrzeby projektu Joint influence of family and labour market participation and fertility decisions of men and women przez E. Słotwińską-Rosłanowską oraz K. Kocot-Górecką.
} 
uzależniający poziom hazardu od zmiennych stałych w czasie $\left(\mathrm{x}_{1}\right)$ i zmiennych zmiennych w czasie $\left(\mathrm{x}_{\mathrm{k}}\right)$. Jako że decyzje prokreacyjne podejmowane są na 9 miesięcy przed urodzeniem dziecka, wartości zmiennych zależnych od czasu, ustalono dla momentu $\mathrm{t}$ na poziomie $\mathrm{t}-9$ miesięcy.

Intensywność przejścia pomiędzy stanami zdefiniowano jako prawdopodobieństwo - na jednostkę czasu - tego, że kobieta, która do określonego momentu była bezdzietna (posiadała jedno dziecko), urodzi pierwsze (drugie) dziecko. Model pokazuje zatem proporcjonalne zmiany ryzyk/hazardów wywoływane jednostkową zmianą określonej zmiennej objaśniającej. Oszacowanie dwóch modeli: modelu przejścia do pierwszego i modelu przejścia do drugiego dziecka dla tych samych kohort urodzeniowych (1960+), pozwala porównać wpływ tych samych zmiennych na decyzje prokreacyjne kobiet nieposiadających dzieci oraz matek, które mają jedno dziecko.

\section{ŹRÓDŁO DANYCH I DOBÓR ZMIENNYCH DO MODELU}

Analizy zostały przeprowadzone na danych pochodzących z pierwszej rundy badania ankietowego Generacje, Rodziny i Płeć Kulturowa (GGS-PL - Generations and Gender Survey), które zrealizowano na losowej próbie 20 tys. respondentów w wieku 18-79 lat w okresie październik 2010 - luty 2011. W badaniu nie ograniczono się do zebrania informacji o aktualnej sytuacji respondenta, ale zanotowano również przebieg jego historii rodzinnej i zawodowej.

Model oszacowano na podstawie podpróby 5501 kobiet urodzonych po 1959 roku, wśród których 1620 było bezdzietnych, 1390 miało jedno dziecko, 1666 - dwoje dzieci, a 825 - troje lub więcej dzieci. Przejścia między wyodrębnionymi stanami ilustruje tablica 1.

Tablica 1. Liczba przejść ze stanu „bezdzietna” do stanu „1 dziecko” oraz ze stanu „1 dziecko” do stanu ,2 dzieci”

Table 1. Number of transitions from ,childless" to , 1 child" and from , 1 child" to ,2 children"

\begin{tabular}{|l|l|}
\hline \multicolumn{2}{|c|}{ liczba obserwowanych przejść (zdarzeń) } \\
\hline ze stanu „bezdzietna” do stanu „1 dziecko” & 3881 \\
\hline ze stanu „1 dziecko” do stanu „2 dzieci” & 2491 \\
\hline
\end{tabular}

Źródło: Obliczenia własne na podstawie danych GGS-PL.

Source: Own calculations based on GGS-PL data set.

Kluczową - z punktu widzenia realizacji celu badania - zmienną objaśniającą w modelu była zmienna opisująca status aktywności zawodowej respondentki. Z uwagi na brak informacji o okresach, w których respondentka była bezrobotna, wyróżniono jedynie dwa stany: pozostawanie w zatrudnieniu i brak zatrudnienia. 
Zmienną tę uwzględniono jako zmienną zmienną w czasie - respondentce przypisano odpowiedni status dla każdego momentu t.

Aby uchwycić w modelu zmienność otoczenia prawnego w zakresie uprawnień rodzicielskich, zdecydowano o włączeniu do modelu zmiennej odzwierciedlającej długość urlopu macierzyńskiego przysługującego respondentce. Uwzględniając fakt, że urlop macierzyński jest uprawnieniem pracowniczym, zastosowano korektę wartości zmiennej, która polegała na przypisaniu respondentkom w okresie, gdy nie pracowały zawodowo (tj. w czasie, gdy nie przysługiwał im urlop macierzyński) wartości zmiennej 0 niezależnie od obowiązujących uregulowań prawnych. Zmienna ta została również ujęta jako zmienna w czasie, a zatem długość przysługującego jednostce urlopu zmieniała się $\mathrm{w}$ czasie $\mathrm{w}$ rezultacie zmian zachodzących $\mathrm{w}$ regulacjach prawnych.

Ponadto w modelu uwzględniono również zmienne kontrolne charakteryzujące społeczno-demograficzne cechy respondentki, miejsce pochodzenia oraz ocenę roli, jaką odgrywała religia w jej domu rodzinnym. Wybór zmiennych kontrolnych podyktowany był uzasadnieniami teoretycznymi, dla których istotność w modelach dzietności została potwierdzona empirycznie dla innych krajów w badaniach innych autorów oraz możliwością pozyskania danych dotyczących ważnych zmiennych $\mathrm{z}$ badania ankietowego, na bazie którego dokonano oszacowań modelu w niniejszym artykule.

Wśród zmiennych odzwierciedlających podstawowe cechy społeczno-demograficzne badanych kobiet należy przede wszystkim uwzględnić wykształcenie kobiety, przy czym można się spodziewać występowania ujemnej zależności między wykształceniem a dzietnością kobiet. Po pierwsze, koszty alternatywne (opportunity costs) macierzyństwa są wyższe dla kobiet z wyższym wykształceniem uzyskujących wyższą płacę (por. Becker 1981; Blossfeld i Huinink 1991). Po drugie, jak wynika z badań socjologicznych, kobiety pochodzące $\mathrm{z}$ różnych środowisk i mające różny dostęp do edukacji posiadają również różne przekonania na temat wyznaczników „sukcesu życiowego" (Edin i Kefalas 2005). Dla kobiet z niższym wykształceniem często posiadanie dziecka jest jednym z głównych, jeśli nie najważniejszym wyznacznikiem życiowego sukcesu. Natomiast kobiety z wyższym wykształceniem to osoby, dla których dziecko jest tylko jednym z wielu elementów niezbędnych do osiągnięcia pożądanego statusu. Takie kobiety oprócz realizacji zamierzeń prokreacyjnych chcą często osiągnąc sukces zawodowy, realizować się w pracy, a także w ramach swoich pozazawodowych pasji. Po trzecie, jak pokazały badania Lundberg i Pollak (2007) dla USA, kobiety z niższym wykształceniem są bardziej skłonne do podjęcia decyzji o posiadaniu dziecku poza małżeństwem niż kobiety z wykształceniem wyższym, co sprzyja większej dzietności tych kobiet. Wyniki części dotychczas prowadzonych badań wskazują na negatywny wpływ wykształcenia kobiety na dzietność (por. Di Tommaso 1999, Rønsen 2004, Adsera 2005, Kreyenfeld 2005, De Laat i Sevilla Sanz 2006, Del Boca i Sauer 2006, Matysiak 2009). 
Wobec braku informacji o przebiegu kariery edukacyjnej badanych kobiet w badaniu GGS-PL, historię wykształcenia respondentki odtworzono na podstawie informacji o jej poziomie wykształcenia w momencie badania, dacie uzyskania najwyższego poziomu wykształcenia oraz typowego przebiegu edukacji w Polsce ${ }^{4}$. Zmienna ta mogła przyjmować wartości z przedziału od 1 do 10 , gdzie wartości 1 przyporządkowano najniższy poziom edukacji (nieukończone wykształcenie podstawowe lub bez wykształcenia), a wartości 10 poziom najwyższy (wykształcenie wyższe ze stopniem naukowym co najmniej doktora). Zmienna ta uwzględniona została $\mathrm{w}$ modelu jako zmienna zmienna w czasie, co pozwoliło uwzględnić momenty przejścia respondentki do kolejnych poziomów wykształcenia.

Jako zmienne kontrolne, w modelu uwzględniono również miejsce pochodzenia respondentki oraz ocenę religijności jej domu rodzinnego. Zmienne te miały na celu odzwierciedlenie tzw. pochodzenia społecznego (social background; por. np. Rønsen 2004 lub Matysiak 2009). Można się bowiem spodziewać, że kobiety pochodzące ze środowisk wiejskich lub mniejszych miast oraz te pochodzące z domów, w których istotną rolę odgrywała religia, będą bardziej skłonne do posiadania więcej niż jednego dziecka. Jak pokazują badania Rønsen (2004) z jednej strony religijność kobiet sprawia, że opóźniają one poczęcie do momentu zawarcia małżeństwa, lecz po jego zawarciu zwiększają ryzyko urodzenia, w szczególności drugiej i trzeciej kolejności w porównaniu do niereligijnych kobiet.

W szacowanym przez nas modelu uwzględniony został także stan cywilny respondentki rozumiany jako stan cywilny prawny ${ }^{5}$. Zebrane w badaniu informacje o historii związków pozwoliły na ujęcie tej zmiennej jako zmiennej w czasie, a zatem respondentkom przypisano odpowiedni stan cywilny na każdym etapie obserwacji. W modelu przejścia do drugiego dziecka uwzględniono również wiek urodzenia przez respondentkę pierwszego dziecka.

Szczegółowe informacje o sposobie kodowania zmiennych zamieszczono w tablicy 2.

4 Metoda stosowana m.in. przez M. Kreyenfeld i J. Hoem (2006)

5 Zebrane w badaniu dane pozwoliły na wyróżnienie jedynie dwóch stanów (wolna, w małżeństwie). Informacje o historii związków respondentki nie uwzględniały bowiem ewentualnego stanu separacji prawnej. 
Tablica 2. Sposób kodowania zmiennych dotyczących charakterystyk respondenta Table 2. Encoding of characteristics of respondents

\begin{tabular}{|l|l|}
\hline \multicolumn{1}{|c|}{$\begin{array}{c}\text { zmienna } \\
\text { variable }\end{array}$} & \multicolumn{1}{c|}{$\begin{array}{c}\text { sposób kodowania } \\
\text { coding }\end{array}$} \\
\hline miejsce zamieszkania & 1 - wieś \\
w dzieciństwie & 2 - małe miasto \\
place of residence in childhood & 3 - duże miasto (tj. miasto powyżej 100 tys. mieszkańców) \\
\hline Wykształcenie & 1 - podstawowe nieukończone \\
education level & 2 - podstawowe ukończone \\
& 3 - gimnazjalne \\
& 4 - zasadnicze zawodowe \\
& 5 - średnie ogólnokształcące \\
& 6 - średnie zawodowe \\
& 7 - policealne \\
& 8 - wyższe licencjackie, inżynierskie lub równorzędne \\
& 9 - wyższe magisterskie lub równorzędne \\
& 10 - wyższe ze stopniem naukowym co najmniej doktora \\
\hline stan cywilny & 0 - nie w małżeństwie \\
marital status & 1 - w małżeństwie \\
\hline rola religii w domu rodzinnym & 1 - bardzo ważna \\
respondentki & 2 - raczej ważna \\
role of religion in respondent's & 3 - ani ważna, ani nieważna \\
family home & 4 - raczej nieważna \\
& 5 - zupełnie nieważna \\
\hline
\end{tabular}

Źródło: Opracowanie własne.

Source: Own elaboration.

\section{WYNIKI ANALIZY}

Tablica 3 przestawia wyniki estymacji modeli dla każdego z analizowanych przejść odrębnie. Poza informacją o oszacowaniu parametru i jego istotności, w tablicy zamieszczono również informację o poziomie współczynnika hazardu (hazard ratio).

Wykształcenie respondentki istotnie determinowało jedynie ryzyko pierwszego urodzenia - respondentki lepiej wykształcone charakteryzowały się znacznie niższym ryzkiem urodzenia, podczas gdy przy przejściu do drugiego dziecka zmienna ta okazała się być nieistotna. Prawdopodobieństwo urodzenia zarówno pierwszego, jak i drugiego dziecka silnie determinował natomiast stan cywilny respondentki - kobiety w małżeństwie charakteryzowały się istotnie wyższym ryzykiem urodzenia dziecka (szczególnie pierwszego) niż kobiety stanu wolnego.

Na ryzyko urodzenia zarówno pierwszego, jak i drugiego dziecka wpływ miało również miejsce zamieszkania respondentki w dzieciństwie. Kobiety, które dorastały w mniejszych miejscowościach charakteryzowały się istotnie wyższym ryzykiem urodzenia niż respondentki wywodzące się z dużych miast. Religijność domu rodzin- 
nego kobiety nie okazała się istotnie determinować ryzyka urodzenia pierwszego dziecka. Natomiast w przypadku dziecka drugiego zmienna okazała się być istotna - kobiety, w domach których religii przypisywano dużą wartość, charakteryzowały się nieznacznie niższym ryzykiem urodzenia dziecka. Prawdopodobieństwo urodzenia drugiego dziecka istotnie zdeterminowane było również wiekiem urodzenia pierwszego dziecka - wraz ze wzrostem wieku urodzenia pierwszego dziecka malało ryzyko urodzenia dziecka drugiego.

Tablica 3. Wyniki estymacji modeli ryzyk proporcjonalnych dla przejścia od stanu „bezdzietny” do stanu „1 dziecko” oraz ze stanu „1 dziecko” do stanu „2 dzieci”

Table 3. Parameters estimates of the proportional hazard model for transition from ,childless” to , 1 child" and from , 1 child" to ,2 children"

\begin{tabular}{|c|c|c|c|c|}
\hline \multirow[b]{2}{*}{$\begin{array}{l}\text { zmienna } \\
\text { variable }\end{array}$} & \multicolumn{2}{|c|}{$\begin{array}{l}\text { przejście ze stanu } \\
\text { „bezdzietna” do stanu „1 } \\
\text { dziecko" } \\
\text { transition from ,childless” to } \\
\text { „1 child” }\end{array}$} & \multicolumn{2}{|c|}{$\begin{array}{l}\text { przejście ze stanu „1 } \\
\text { dziecko" do stanu „2 dzieci” } \\
\text { transition from „, } 1 \text { child” to } \\
, 2 \text { children” }\end{array}$} \\
\hline & $\begin{array}{l}\text { oszacowanie } \\
\text { parametru } \\
\text { estimate }\end{array}$ & $\begin{array}{l}\text { hazard } \\
\text { ratio }\end{array}$ & $\begin{array}{l}\text { oszacowanie } \\
\text { parametru } \\
\text { estimate }\end{array}$ & $\begin{array}{l}\text { hazard } \\
\text { ratio }\end{array}$ \\
\hline $\begin{array}{l}\text { miejsce zamieszkania } \\
\mathrm{w} \text { dzieciństwie } \\
\text { place of residence in childhood }\end{array}$ & $-0,103 * * *$ & 0,901 & $-0,236^{* * *}$ & 0,790 \\
\hline $\begin{array}{l}\text { wykształcenie } \\
\text { education level }\end{array}$ & $-0,024 * *$ & 0,976 & $-0,018$ & 0,982 \\
\hline $\begin{array}{l}\text { rola religii } \mathrm{w} \text { domu rodzinnym } \\
\text { respondentki } \\
\text { role of religion in respondent's } \\
\text { family home }\end{array}$ & $-0,024$ & 0,976 & $-0,085^{* * *}$ & 0,918 \\
\hline $\begin{array}{l}\text { stan cywilny } \\
\text { marital status }\end{array}$ & $1,969 * * *$ & 7,168 & $0,546^{* * *}$ & 1,726 \\
\hline $\begin{array}{l}\text { wiek urodzenia pierwszego } \\
\text { dziecka } \\
\text { age at first birth }\end{array}$ & $X$ & $X$ & $-0,083 * * *$ & 0,921 \\
\hline $\begin{array}{l}\text { zatrudnienie } \\
\text { employment status }\end{array}$ & $0,513 * * *$ & 1,668 & $1,018^{* * *}$ & 2,767 \\
\hline $\begin{array}{l}\text { długość urlopu macierzyńskiego } \\
\text { skorygowana o status aktywności } \\
\text { respondenta na rynku pracy } \\
\text { length of maternity leave adjusted } \\
\text { for respondent's employment } \\
\text { status }\end{array}$ & $-0,008$ & 0,992 & $-0,045^{* * *}$ & 0,956 \\
\hline
\end{tabular}

Uwagi/Notes: ${ }^{* *} p<0,01 ; * * p<0,05 ; \quad * p<0,1$

Źródło: Obliczenia własne na podstawie danych GGS-PL.

Source: Own calculations based on GGS-PL data set. 
Zmienną silnie determinującą intensywność przejść do pierwszego i drugiego dziecka była aktywność respondentki na rynku pracy. Kobiety pracujące zawodowo na 9 miesięcy przed urodzeniem dziecka cechowały się znacznie wyższą intensywnością przejścia zarówno do rodzicielstwa w ogóle, jak i do drugiego dziecka niż kobiety nieposiadające pracy.

Wbrew oczekiwaniom długość prawnie przysługującego urlopu macierzyńskiego jedynie nieznacznie determinowała ryzyko urodzenia drugiego dziecka. Zaskakujący był również kierunek działania tej zmiennej - dłuższy urlop macierzyński zmniejszał ryzyko urodzenia. Wpływ ten jednak, choć istotny statystycznie, był bardzo słaby.

\section{PODSUMOWANIE I WNIOSKI}

Ważnym wynikiem zaprezentowanych analiz jest stwierdzenie występowania pozytywnego, statystycznie istotnego wpływu zatrudnienia kobiet na ryzyko urodzenia zarówno pierwszego, jak i drugiego dziecka. Wyniki te zdają się potwierdzać sformułowaną przez Matysiak (2009) tezę, że dla polskich kobiet, które weszły na rynek pracy, zatrudnienie jest warunkiem, a nie barierą dla posiadania dzieci. W odróżnieniu od wyników Lalive i Zweimuller (2005) dla Austrii, długość prawnie przysługującego matkom urlopu macierzyńskiego w Polsce okazała się nie mieć istotnego pozytywnego wpływu na ryzyko urodzenia dziecka. Wydaje się więc, że nie ma podstaw do oczekiwań, że wydłużanie tego urlopu istotnie przyczyni się do zwiększenia dzietności. Należy mieć jednak na uwadze to, że negatywny związek długości przysługującego urlopu i dzietności może być wynikiem oddziaływania innych zmiennych kontekstowych (m.in. sytuacji ekonomicznej w kraju), nieuwzględnionych dotąd $\mathrm{w}$ modelu ${ }^{6}$. Słaby wpływ zmian w długości urlopów macierzyńskich na dzietność może wynikać również z tego, że większość dokonywanych zmian była krótkotrwała lub/i zmiany te były nieznaczne (por. wykres 2 zamieszczony w Aneksie). Jedyna istotna zmiana długości urlopu, jaka miała miejsce po 1974 a przed 2002 rokiem (spadek z 26 do 20 tygodni przy pierwszym pojedynczym porodzie w 2000 roku), była incydentalna i trwała zaledwie niecały rok. Reformy urlopów od 2006 roku były z kolei bardzo niewielkie (wzrost długości urlopu przeciętnie poniżej 2 tygodni rocznie). W celu weryfikacji uzyskanych w niniejszej pracy wyników autorki planują przeprowadzenie kolejnych badań z wykorzystaniem drugiej fali badania GGS-PL, które będzie zrealizowane w 2014 roku.

Wyniki oszacowanego modelu potwierdzają natomiast rezultaty części wcześniejszych badań realizowanych w wielu krajach europejskich, w tym w Polsce, wskazujące na negatywny wpływ wzrostu wykształcenia na prawdopodobieństwo przejścia do macierzyństwa (por. Blossfeld i Huinink 1991, Brewster i Rindfuss

6 Autorki obecnie pracują nad rozszerzeniem analiz uwzględniających szersze spektrum zmiennych odzwierciedlających kontekstowe uwarunkowania ekonomiczne i strukturalne decyzji prokreacyjnych. 
2000, Caucutt i in. 2002, Martín-García i Baizán 2005, Spain i Bianchi 1996). Prawdopodobnie oddziałuje tu czynnik zróżnicowanych kosztów alternatywnych oraz różnych wyznaczników „sukcesu życiowego”. Wyższa potencjalna płaca (koszt alternatywny) oraz mniejsza rola posiadania dziecka w osiąganiu sukcesu życiowego, w przypadku kobiet z wyższym wykształceniem, sprawiają, że kobiety te mają niższą dzietność. Dodatkową rolę odgrywać może także większa skłonność kobiet z niższym wykształceniem do poczęcia i rodzenia dzieci poza małżeństwem, co ostatecznie również skutkuje wyższą dzietnością (por. Lundberg i Pollak 2007).

\section{LITERATURA:}

Adsera A., 2005, Vanishing children: From high unemployment to low fertility in developed countries, „American Economic Review”, 95(2), 189-193.

Andersson G., Duvander A.-Z., Hank K., 2004, Do child-care characteristics influence continued childbearing in Sweden? An investigation of the quantity, quality, and price dimension, ,Journal of European Social Policy", 14, 407-418.

Andersson G., Hoem J.M., Duvander A.-Z., 2006, Social differentials in speed-premium effects in childbearing in Sweden, „Demographic Research”, 14(4), 51-70.

Baizán P., 2005, Couples' careers and fertility: An event history analysis of the ECHP samples of Denmark, Italy, Spain, and United Kingdom, paper presented at the XXV International Population Conference, Tours, France, July 18-23, 2005.

Becker G.S., 1981, Altruism in the family and selfishness in the market place, „Economica”, 48(189), $1-15$.

Bjorklund A., 2006, Does family policy affect fertility? Lessons from Sweden, „Journal of Population Economics", 19(1), 3-34.

Blossfeld H.-P., Huinink J., 1991, Human capital investments or norms of role transition? How women's schooling and career affect the process of family formation, „The American Journal of Sociology”, 97(1), 143-168.

Brewster K.L., Rindfuss R.R., 2000, Fertility and women's employment in industrialized nations, „Annual Review of Sociology”, 26, 271-296.

Büttner T., Lutz W., 1990, Estimating fertility responses to policy measures on the German Democratic Republic, „Population and Development Review”, 16(3), 539-555.

Castles F.G., 2003, The world turned upside down: Below replacement fertility, changing preferences and family-friendly public policy in 21 OECD countries, „Journal of European Social Policy”, 13(3), 209-229.

Caucutt E.M., Nezih G., Knowles J., 2002, Why do women wait? Matching, wage inequality, and the incentives for fertility delay, „Review of Economic Dynamics”, 5, 815-855.

Cigno A., Ermisch J., 1989, A microeconomic analysis of the timing of births, „European Economic Review", 33, 737-760.

De Laat J., Sevilla Sanz A., 2006, Working women, men's home time and lowest-low fertility, ISER Working Paper, 2006-23, Colchester, University of Essex.

Del Boca D., 2002, Mothers, fathers and children after divorce: The role of institutions, IZA Discussion Papers, no. 428, Institute for the Study of Labor, Bonn.

Del Boca D., 2002, The effect of child care and part-time opportunities on participation and fertility decisions in Italy, "Journal of Population Economics", 15, 549-573.

Del Boca D., Sauer R., 2006, Lifecycle employment and fertility across institutional environments, IZA Discussion Papers, no. 2285, Institute for the Study of Labor, Bonn. 
Di Tommaso M.L., 1999, A trivariate model of participation, fertility and wages: the Italian case, „Journal of Cambridge Economics”, 23, 623-640.

Edin K., Kefalas M.J., 2005, Promises I Can Keep: Why Poor Women Put Motherhood Before Marriage, University of California Press, Berkeley.

Ekert O., 1986, Effets et limites des aides financieres aux families. Une experience et un modele, „Population”, 2, 327-348.

Ermisch J.F., 1991, Economic models of women's employment and fertility. [w:] Siegers J.J., de JongGierveld J., van Imhoff E. (red.), Female Labour Market Behaviour and Fertility: A Rational-Choice Approach (s. 175-190), Springer, Berlin.

Gauthier A.H., Hatzius J., 1997, Family benefits and fertility: An econometric analysis, „Population Studies", 51, 295-306.

Hank K., Kreyenfeld M., 2003, A multilevel analysis of child care and women's fertility decisions in Western Germany, „Journal of Marriage and the Family”, 65, 584-596.

Hoem B., 2000, Entry into motherhood in Sweden: The influence of economic factors on the rise and fall in fertility, 1986-1997, „Demographic Research”, 2, Article 4.

Hoem J.M., 1993, Public policy as the fuel of fertility: Effects of a policy reform on the pace of childbearing in Sweden in the 1980s, „Acta Sociologica”, 36(1), 19-31.

Hoem J.M., Prskawetz A., Neyer G., 2001, Autonomy or conservative adjustment? The effect of public policies and educational attainment on third births in Austria, 1975-96, „Population Studies”, 55(3), 249-261, reprinted in the „Vienna Yearbook of Population Research”, 2003, 101-119.

Hyatt D., Milne W., 1991, Can public policy affect fertility?, „Canadian Public Policy/Analyse de Politiques", 27(1), 77-85.

Kocot-Górecka K., Kurowska A., 2013, Znaczenie sytuacji rodzinnej i postaw wobec kulturowych ról ptci dla zatrudnienia matek małych dzieci w Polsce, ISiD Working Paper.

Kotowska I.E., 2002, Zmiany modelu rodziny. Polska-kraje europejskie, „Polityka Społeczna” nr 4, 2-7.

Kotowska I.E., 2004, Zmiany demograficzne a przyszły rynek pracy, [w]: S. Borkowska (red.), Przyszłość pracy w XXI wieku, IPiSS - Główny Urząd Statystyczny, Warszawa.

Kreyenfeld M., 2005, Economic uncertainty and fertility postponement: Evidence from German panel data, MPIDR Working Paper, no. 2005-034, Max Planck Institute for Demographic Research, Rostock.

Kreyenfeld M., Hoem J., 2006, Anticipatory analysis and its alternatives in life-course research: Part 1: Education and first childbearing, „Demographic Research”, 15, Article 16.

Kurowska A., 2013, Ocena zasadności zatożeń reformy urlopów i zasitków zwiazanych z opieka nad małym dzieckiem, „Problemy Polityki Społecznej. Studia i Dyskusje”, nr 21, 155-170.

Lalive R., Zweimuller J., 2005, Does parental leave affect fertility and return-to-work? Evidence from a 'true natural experiment', IZA Discussion paper, no. 1613, Institute for the Study of Labor, Bonn.

Laroque G., Salanié B., 2005, Does fertility respond to financial incentives?, C.E.P.R. Discussion Papers, no. 5007.

Liefbroer A.C., Corijn M., 1999, Who, what, where, and when? Specifying the impact of educational attainment and labour force participation on family formation, „European Journal of Population”, 15(1), 45-75.

Lundberg S., Pollak R.A., 2007, The American family and family economics, „Journal of Economic Perspectives", 21(2), 3-26.

Martín-García T., Baizán P., 2005, The impact of the type of education and of educational enrolment on first births, „European Sociological Review”, 22 (3), 259-275.

Matysiak A., Vignoli D., 2008, Fertility and women's employment: a meta-analysis, „European Journal of Population", 24(4), 363-384.

Matysiak A., 2009, Employment first, then childbearing: women's strategy in post-socialist Poland, „Population Studies”, 63(3), 253-276.

Matysiak A., 2011, Interdependencies Between Fertility and Women’s Labour Supply, „European Studies of Population", vol. 17. 
Milligan K., 2005, Subsidizing the stork: New evidence on tax incentives and fertility, „Review of Economics and Statistics", 83, 539-555.

Muszyńska M., 2003, Zróżnicowanie modeli rodziny w krajach europejskich w kontekście statusu kobiety w spoleczeństwie, ,Studia Demograficzne”, nr 2/144, 55-77.

Neyer G., Andersson, G., 2008, Consequences of family policies on childbearing behavior:Effects or artifacts?, „Population and Development Review”, 34(4), 699-724.

Olah L.S., 2003, Gendering fertility: Second births in Sweden and Hungary, „Population Research and Policy Review", 22, 171-200.

Olausson P., Bengt H., Cnattingius S., 2001, Teenage childbearing and long-term socioeconomic consequences: A case study in Sweden, „Family Planning Perspectives”, 33(2), 70-74.

Rindfuss R.R., Guilkey D.K., Morgan S.P., Kravdal Ø., 2010, Child-care availability and fertility in Norway, „Population and Development Review”, 36(4), 725-748.

Rønsen M., 1999, Impacts on fertility and female employments of parental leave programs: Evidence from nordic countries. Paper presented at the EPC Conference, the Hague, 1999.

Rønsen M., 2004, Fertility and public policies: Evidence from Norway and Finland, „Demographic Research", 10, 143-170.

Spain D., Bianchi S., 1996, Balancing Act: Motherhood, Marriage, and Employment Among American Women, Russell Sage Foundation, New York.

Vikat A., 2004, Women's labor force attachment and childbearing in Finland. „Demographic Research”, 3 (Article 8), 175-212.

Walker J., 1995, The effect of public policies on recent Swedish fertility behavior. „Journal of Population Economics", 8(3), 223-51.

Zhang J., Quan J., Van Meerbergen P., 1994, The effect of tax-transfer policies on fertility in Canada, 1921-88, „The Journal of Human Resources”, 29(1), 181-201. 


\section{ANEKS}

Wykres 2. Zmiany wskaźnika dzietności ogólnej (TFR) na tle zmian w długości prawnie przysługującego urlopu macierzyńskiego w Polsce w latach 1995-2011.

Figure 2. Trends in total fertility rate (TFR) and the number of weeks of the fully paid maternity leave entitlement in Poland in 1995-2011

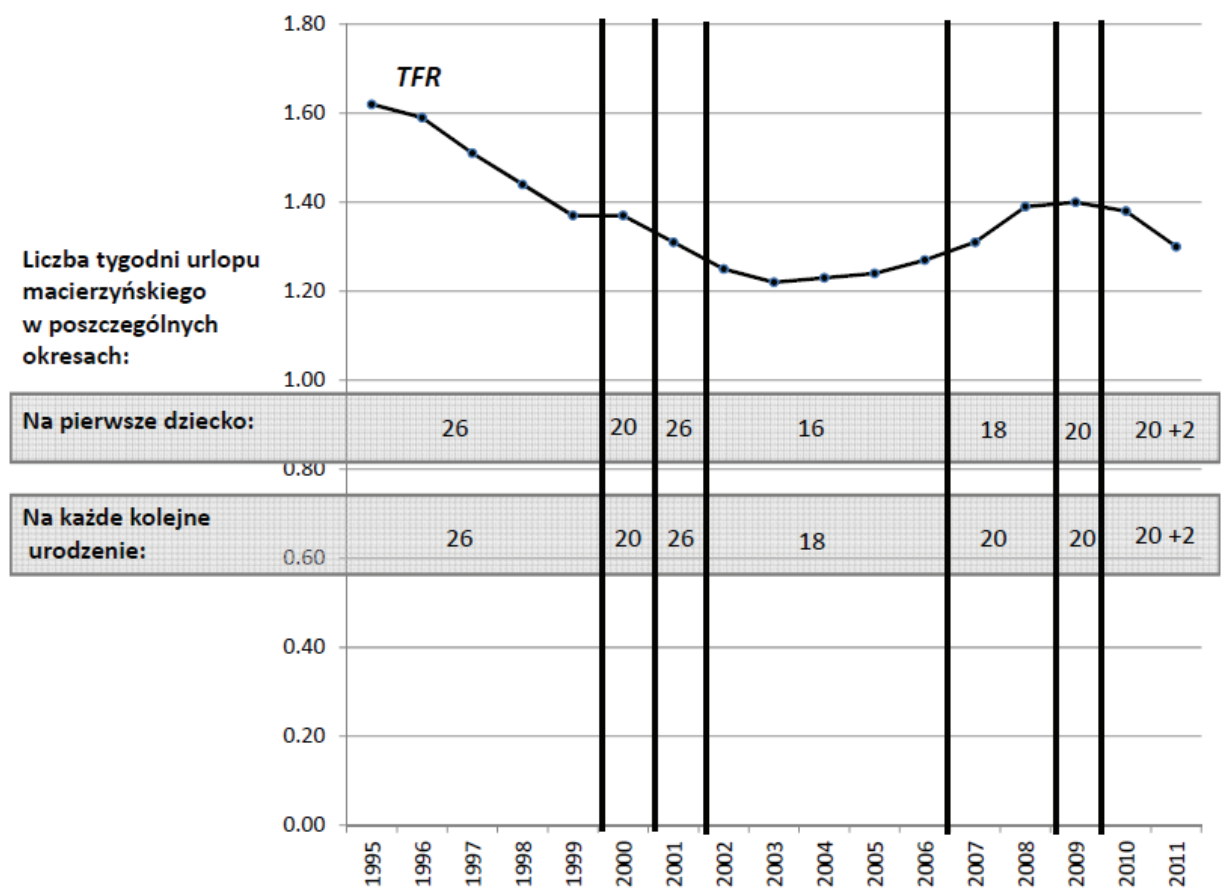

Źródło: Opracowanie własne na podstawie danych z bazy Eurostat.

Source: Own elaboration based on data from the Eurostat database. 


\title{
THE ROLE OF EMPLOYMENT STATUS FOR FIRST AND SECOND CHILDBIRTHS OF WOMEN IN POLAND
}

\begin{abstract}
The paper presents results of estimation of Cox proportional hazard model developed in order to identify the importance of employment for a first and a second childbirth for Polish women born in 1960 and after. The analysis is based on data from the first wave of the Generations and Gender Survey GGS-PL.

The results show: a) positive and statistically significant effect of employment on the risk of having a first and a second child, $b$ ) negative, although weak impact of the length of statutory maternity leave on the risk of having a second child. The results cast in doubt the effectiveness of the new reform that introduces the possibility of taking longer maternity leaves in order to boost fertility.
\end{abstract}

Keywords: childbearing, fertility, employment, maternity leave, Cox 